\title{
Simulation in Healthcare in the Realm of Education 4.0
}

(Simulasi dalam Penjagaan Kesihatan di Alam Pendidikan 4.0)

\section{Zaleha Abdullah Mahdy, Muhammad MaAya, Ixora Kamisan Atan, Azlan Helmy Abd Samat, Mohd HISHAM ISA \& ISMAIL MOHD SAIBOON*}

\begin{abstract}
The advent of Education 4.0, in parallel with Industrial Revolution (IR) 4.0, has translated into an evolution in healthcare education. Simultaneously, as a result of concerns in doctors' competency and patient safety, simulation shot into center-stage in the field of healthcare education. Generally, there are five modalities in healthcare education, namely role-play (verbal), standardized patient, part-task trainer, computer or screen-based simulation, and electronic patients including virtual reality. Dissecting the nine principles of Education 4.0, this article reviews the relevance and role of the five different modalities of simulation in easing healthcare education into the mold of Education 4.0.
\end{abstract}

Keywords: Education 4.0; healthcare; industrial revolution; mobile learning; simulation

\section{ABSTRAK}

Kemunculan Pendidikan 4.0, selari dengan Revolusi Industri (IR) 4.0 telah melahirkan sebuah evolusi dalam pendidikan penjagaan kesihatan. Seiring dengan perkembangan tersebut serta kebimbangan mengenai kecekapan para doktor dan keselamatan para pesakit, simulasi menyerlah sebagai salah satu kaedah yang penting dalam bidang pendidikan penjagaan kesihatan. Pada umumnya terdapat lima modaliti simulasi kesihatan iaitu lakonan (bertutur), pesakit piawai, simulator-tugasan-separa, simulasi komputer atau berasaskan skrin dan pesakit elektronik termasuk realiti maya. Dengan merujuk kepada prinsip Pendidikan 4.0, kertas ini mengulas kerelevanan dan peranan yang dimainkan oleh kelima-lima modaliti tersebut dalam pendidikan penjagaan kesihatan berasaskan simulasi dalam kerangka wadah Pendidikan 4.0.

Kata kunci: Pembelajaran bergerak; pendidikan 4.0; penjagaan kesihatan; revolusi industri 4.0; simulasi

\section{INTRODUCTION}

Over the last few centuries, the world has been greatly shaped by four industrial revolutions (IR): The steam engine (IR 1.0); The production line (IR 2.0); The computer (IR 3.0); and The internet (IR 4.0) (Intelitek 2018), with the latest revolution merging the physical and virtual domains. Healthcare education is no exception in having to keep up with the latest ideas and practice of education in general, which must be kept abreast with the industrial revolutions. It is unreasonable to stick to older methods of teaching and learning when the needs of the healthcare profession has changed in line with IR 4.0. To reach out towards an improved outcome, a paradigm shift is in order. New objectives and aspirations require a new mindset and skillset, accompanied by new tools and armamentarium. Medical education must gear itself towards competency based education with the aim of achieving mastery skills rather than remaining merely knowledge based.

Simulation is a technique to replace or amplify real patient experiences with guided experiences that are artificially contrived and evokes or replicates substantial aspects of the real world in a fully immersive and interactive manner (Gaba 2004). It is mainly used as a teaching and learning method, apart from assessment and research (Ismail et al. 2019), having been practiced in various other fields outside healthcare such as aviation, judicial, and military education (Riley 2015). In healthcare education, simulation is in fact not new either, and has been in practice since ancient Chinese civilization. More recently, simulation has revolutionized healthcare education, with much renewed interest and scaling greater heights in terms of usage, variety, and creativity. Apart from formal teaching and learning, simulation plays an important role in preparing healthcare workers in anticipation of managing crisis and disease outbreaks, like the recent COVID-19 pandemic (Wong et al. 2020). The rapid progress in electronics, communication technology and artificial intelligence has enhanced the world of simulation in healthcare education to a huge extent. 


\section{WHAT IS EDUCATION 4.0?}

Education 4.0 came into existence in response to the needs of IR 4.0, each version of 'Education' having been tied to its corresponding 'IR' counterpart, from 1.0 onwards (Hussin 2018). I IR R 4.0 signified Computer Connectivity, i.e. The Internet, and encompasses connections between computers, robots, printers, and the Internet of Things (IoT). Whilst some claim that IR 4.0 is still ongoing, others argue that we are presently sitting on the threshold of IR 5.0 (Intelitek 2018) that deals with personalization.

There are nine principles or features that describe Education 4.0 (Fisk 2017): A learning process unlimited by time and place; Personalized learning; Learning tools customized to the learner's choice; Projectbased learning; Hands-on and experiential learning; Data interpretation; Formative and workplacebased assessment; Learners' feedback in shaping the curriculum design and review; and Independent learning whilst teachers facilitate.
The delivery of healthcare education is no exception in the need to conform to Education 4.0 for the greater good of mankind. The nine tenets of Education 4.0 must be able to impart the desired learning outcomes in healthcare education. The Malaysian Qualifications Framework (MQF) outlines ten learning outcome domains (Figure 1) for any discipline, which correlates well with the six core competencies put forth by the Accreditation Council for Graduate Medical Education (ACGME) and the American Board of Medical Specialties (Satava 2009) which are: Interpersonal and communication skill, medical knowledge, patient care, practice-based learning and improvement, system-based practice, and professionalism. The Canadian CanMEDs 2005 Framework describes seven key competencies required in a medical practitioner in order to provide high quality care (Figure 2), which again conforms to the previous two sets of learning domains (Aggarwal et al. 2010).

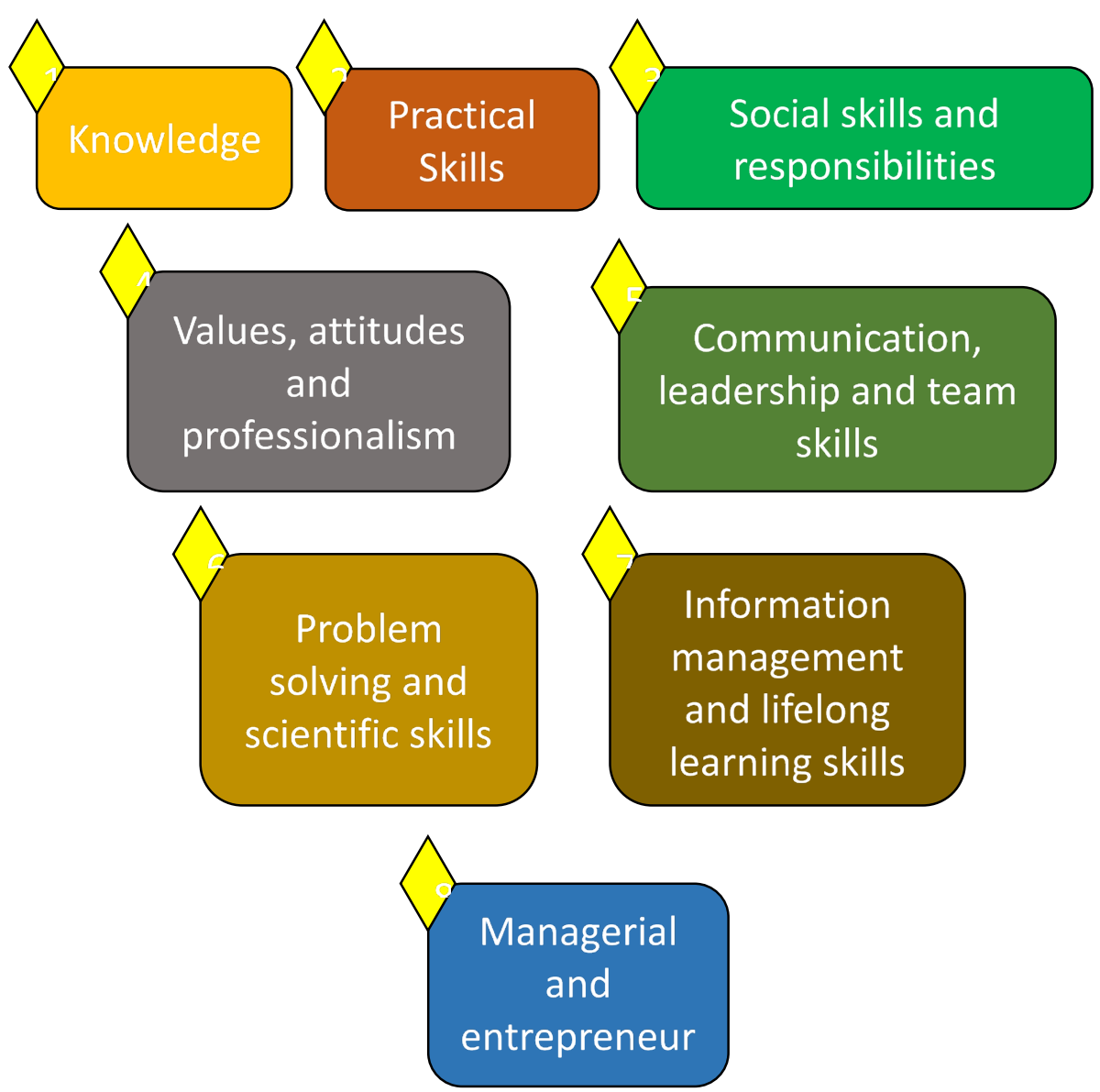

FIGURE 1. The Malaysian Qualifications Framework set of learning outcome domains (O’Brien 2015) 


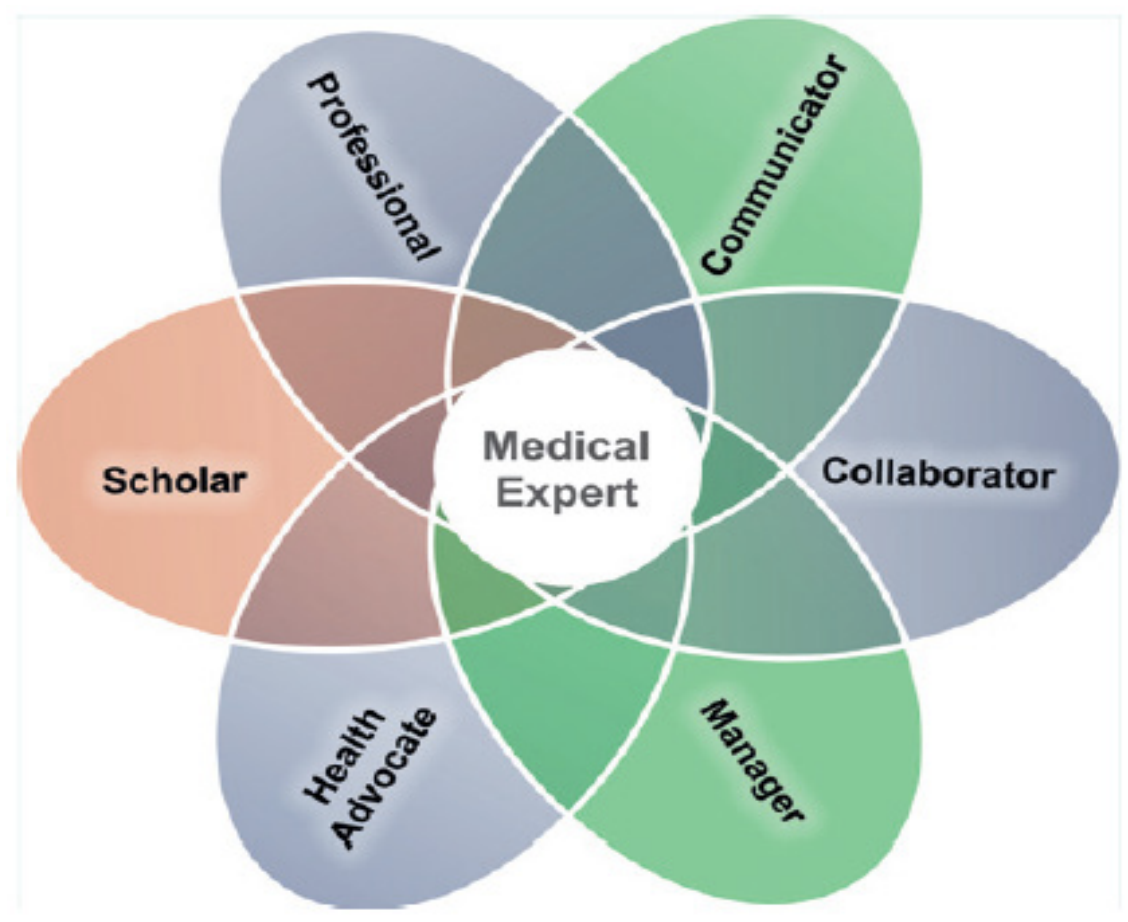

FIGURE 2. The CanMEDs framework comprising seven key competencies required of a doctor to provide high quality care (Aggarwal et al. 2010)

\section{SIMULATION IN HEALTHCARE EDUCATION}

According to Gaba (2004) there are several modalities in healthcare simulation which include verbal (role playing), standardized patients (actor/s), part-task trainers (physical and virtual reality), computer patient or screen-based simulation (computer screen, screen based 'virtual world'), and electronic patient (replica of clinical site, mannequin based, full virtual reality) (Cooper \& Taqueti 2004).

Simulation in healthcare education strives to achieve two objectives - assurance of clinical competence of the healthcare worker, and maintenance of patient safety. Fidelity, which is the degree of similarity to reality of the simulation technique or scenario, depends heavily on the creativity of the module, program design and the conduct of the simulation. There is no direct correlation between the level of simulation technology and the quality of the fidelity. Thus, low technology simulation does not equate low fidelity and similarly, high technology (hence, usually high cost) simulation does not necessarily translate into high fidelity. This is one mistake frequently committed by a person who is unfamiliar in choosing simulators. Regardless of the cost, all simulators are precious. They are not mere toys - they are generally expensive items that should be responsibly purchased, wisely used and well-maintained.

HOW DOES SIMULATION FULFILL THE PRINCIPLES OF

\section{EDUCATION 4.0?}

IR 4.0 has significant impact on the skills required of a healthcare worker, hence it is only reasonable for healthcare educational principles and practice to comply with Education 4.0. For example, the advent of electronic connectivity is accompanied by remote control mechanisms leading to robotics surgery. The lesson learnt from the dawn of laparoscopic surgery is that the insufficient numbers of competent laparoscopic surgeons to teach the skill at that time led to inadequate supervision and training, with disastrous consequences. This has given emphasis to the importance of alternative training methods, which include simulation. Simulation offers the capacity for deliberate practice, which allows skills to be developed by repetitive and focused training in an alternative artificial setting without compromising patient safety or imposing unnecessary stress to the trainee. 


\section{TIMELESS LEARNING ANYWHERE}

Simulation enhances temporal and spatial learning accessibility to a previously unimaginable extent. Programs depicting computer patients allow the practice of screen-based simulation. These programs can easily be uploaded to any online platform that is readily accessible by learners through an asynchronous learning modality. Computer patients allow the recreation of real life clinical case scenarios like managing emergency situations, and practicing the proper steps of surgical procedures, as well as the skill of making the right decision in any given clinical situation. Screen-based simulation promotes cognitive training that can be done at any time and in any location according to learners' preference.

Apart from cognitive training, simulation modalities like part-task trainer and virtual reality (VR) also support training of psychomotor skills or procedures. The presence of flexible access open simulation laboratories, help learners practice some of the important basic as well as advanced procedural skills before they are allowed to perform on real patients. One example is the open learning concept in certain medical schools in Kuala Lumpur, where medical students are allowed access to simulation laboratories at their convenience, in order to practice procedures whilst watching related videos provided on site. In UKM, through such self-instructionalvideo (SIV) (Ismail et al. 2014) that is easily accessible online, medical students can practice on their own, after which they capture their performance of the procedure and send it to supervisors for a more personalized coaching, without any face to face encounter with the supervisor. This frees up considerable time for the lecturers and allows students to practice as much as they wish. At the other end of the technology spectrum, task trainers for robotic surgery allows surgeons to practice the procedures before they perform it on real patients. Compared to basic task trainers, advanced robotic simulators may be less transportable, although temporal accessibility may be unlimited.

VR simulation helps solve some of the procedural skill training accessibility in terms of time and location. Not only does it allow flexible learning opportunities, it also fills the learning gap for cases, clinical scenarios or situations that are infrequently or rarely encountered, e.g. mass disaster response in emergency medicine, prolapse of the umbilical cord or shoulder dystocia in obstetrics, and many other uncommon situations, which are unique to various disciplines of medicine.

\section{PERSONALIZED LEARNING}

Most simulation modalities promote personalized learning, especially role play, part-task trainer, and screen-based and electronic patients including VR, by artificially contriving real patient experiences. In fact, usage of standardized patients (SP) also allows personalized learning depending on SP availability with some additional cost. Learning by simulation is generally customizable to the learner's own pace and time, and learning style. The learner may learn repetitively to gain competency with neither penalty nor negative repercussions, with no threat to patient safety in the case of procedural tasks (Issenberg et al. 2005). Learning either knowledge or skills can also be achieved on a one to one level of supervision.

\section{CUSTOMIZED LEARNING TOOLS}

Apart from the difference in the time taken to gain skills, each person learns best by different methods. The spectrum of simulation modalities that is available provides a variety of learning tools (screen-based, role play, and electronic patient) for the learner to conveniently choose from. The choice of learning tool is indeed important, as learners will be able to learn better when using methods of learning that suits them best. Different learning tools have different learning tasks that are best suited to each individual. For example, if a learner wishes to know how to treat a patient in cardiac arrest, apart from simply reading about it, he/she can learn and practice through electronic patient simulation, or VR simulation or screen-based patient simulation. All these modalities allow learners to manage patients and perform important clinical skills, and decision making. Moreover, the chosen tool can be personalized to enhance the learning experience, e.g. the AHA HeartCode ${ }^{\mathrm{TM}}$ (Montgomery et al. 2012).

\section{PROJECT BASED LEARNING}

Simulation opens up the opportunity to project based learning which underpins organizational, collaborative and time management skills. Through simulation, learners can be given a project or clinical problem, and teachers can see how they work together through the project. Furthermore, enhancement of team work is one of the benefits underlying simulation-based learning. Improving coordination and communication within a team is the key aim of certain simulation-based learning tools, especially scenario-based simulation e.g. enhancing the usage of ISBAR (Identification, Situation, Background, Assessment, Recommendation) (Horgan 2013). In fact, due to the characteristic advantage of simulation (Issenberg et al. 2005), learners can be exposed to different levels of task difficulties and capture multiple variations in the task. One example of implementing this is through Problem Based Learning (PBL) either with screen-based simulation, or augmented or VR simulation. PBL may be conducted using a screenbased computer simulation such as the DxR Clinician ${ }^{\odot}$ (Fida \& Kassab 2015). Learners can work in groups to discuss what and how best to manage clinical problems 
or cases. In fact, during the COVID-19 pandemic, PBL through screen-based simulation has been utilised to help in teaching medical students in UKM.

\section{HANDS-ON AND EXPERIENTIAL LEARNING}

Not every medical practitioner in their junior years is fortunate enough to encounter opportunities to learn various procedures whilst on clinical duty. Even when a rare opportunity arises, there may be more than one trainee eagerly awaiting the chance to perform the task. Besides, one chance will definitely not be adequate to fulfill the need to attain competence. The old adage of 'see one, do one, teach one' is no longer applicable, particularly in this era of litigation and social media complaints. This is where simulation gives a great edge. Through simulation, deliberate practice leading to mastery learning offers a significant advantage. Roleplay can be used to teach communication skills; part-task trainers allow repeated chances to perform specific skills e.g. endotrachael intubation; electronic patient simulation provides the chance to have a life-like resuscitation code team training or an acute crisis resource management. Rare or uncommon procedures can be taught effectively through simulation, thereby overcoming learning merely by chance, which is often inadequate and dangerous in developing the competence of a healthcare personnel.

With the advent of newer devices, skills related to older equipment can deteriorate. There are crucial times when the usage of these older devices are either essential or is the only safe option for managing a patient. Deskilling of using these older but still useful devices, such as the fiberoptic intubating scope, can also be prevented via simulation.

\section{DATA INTERPRETATION}

Data can be created from real life patients or invented based on logic and used to assess knowledge repeatedly in various simulation modalities, e.g. role play, screenbased, virtual or web-based modules. Simulation offers an ideal opportunity for learners to interpret data while they are at the bedside. Solutions or applications that can vary the patient's vital signs and allow the learner to interpret and respond to the situation accordingly, either in an emergency or non-emergency situation, provide learning opportunities that can only come with simulation. There are several applications available nowadays that are easily accessible, either web-based or simulator-based e.g. Vital Sign Simulator \& Patient Monitor ${ }^{\odot}$, which is freely downloadable from the internet (healthysimulation.com) or iSimulate ${ }^{\odot}$ (isimulate.com) simulator.

\section{FORMATIVE ASSESSMENT}

Simulation provides for formative assessment with opportunity for improvement through repetitive practice, and the subject matter that is assessed are practical skills required at the workplace. This form of assessment is indeed the fundamental objective of simulationbased education. The current trend is to move towards this mode of assessment, especially for postgraduate clinical specialty training (Humphrey-Murto et al. 2017). Formative assessment, in the realm of competency based training, allows the learner ample room for improvement in a safe and non-threatening environment. Feedback can be immediate, formative and repetitive, hence accelerating learning in the form of deliberate practice. This forms the Rapid Cycle Deliberate Practice (RCDP) of simulation (Taras \& Everett 2017). Immersive simulation through high fidelity modules enhances a more realistic formative assessment for the learner. This can be achieved through electronic patient simulation or VR.

\section{LEARNERS AS STAKEHOLDERS IN CURRICULUM DEVELOPMENT}

The development of a curriculum based on simulation techniques is dynamic as the interaction between students and module developers (who are usually the trainers) happens continuously and ends with feedback and evaluation of the session. The cycle of simulation teaching-learning is vital in simulation-based healthcare education (Figure 3) (Nestel \& Gough 2018). Preparation, briefing and orientation, simulation activity, debriefing, reflection, and evaluation are important steps to be followed. During evaluation, assessing the effectiveness of the scenario based on learners' feedback and performance is of utmost importance. Through this, simulation teaching has become a natural way of how a student or learner contributes to the development of the curriculum that fits their purpose or objective. This constant engagement ensures a continuum of opportunity for improvement of the training module and allows learners to get involved in planning their learning process. Learners therefore contribute to the simulation module design by participating in the decision-making of what is the best way to acquire certain knowledge or skillset in their curriculum.

\section{TEACHERS AS FACILITATORS OF INDEPENDENT LEARNERS}

The concept of heutagogy (self-directed learning) is the foundation of most simulation modules. In medical education, self-directed personal learning, either alone or more often in a small group, have long been practiced, guided by lecturers. With the widespread use of electronic media and gadgets in learning, the principle of heutagogy is further strengthened in learning by simulation. As mentioned earlier, most simulation modalities support this concept of students becoming independent learners. Part-task trainers, screen-based or computer patients, electronic patients with VR, all promote self-directed learning. Teachers no longer need to dictate or supervise directly but merely observe, facilitate and debrief. This augurs well with the last tenet of Education 4.0. 


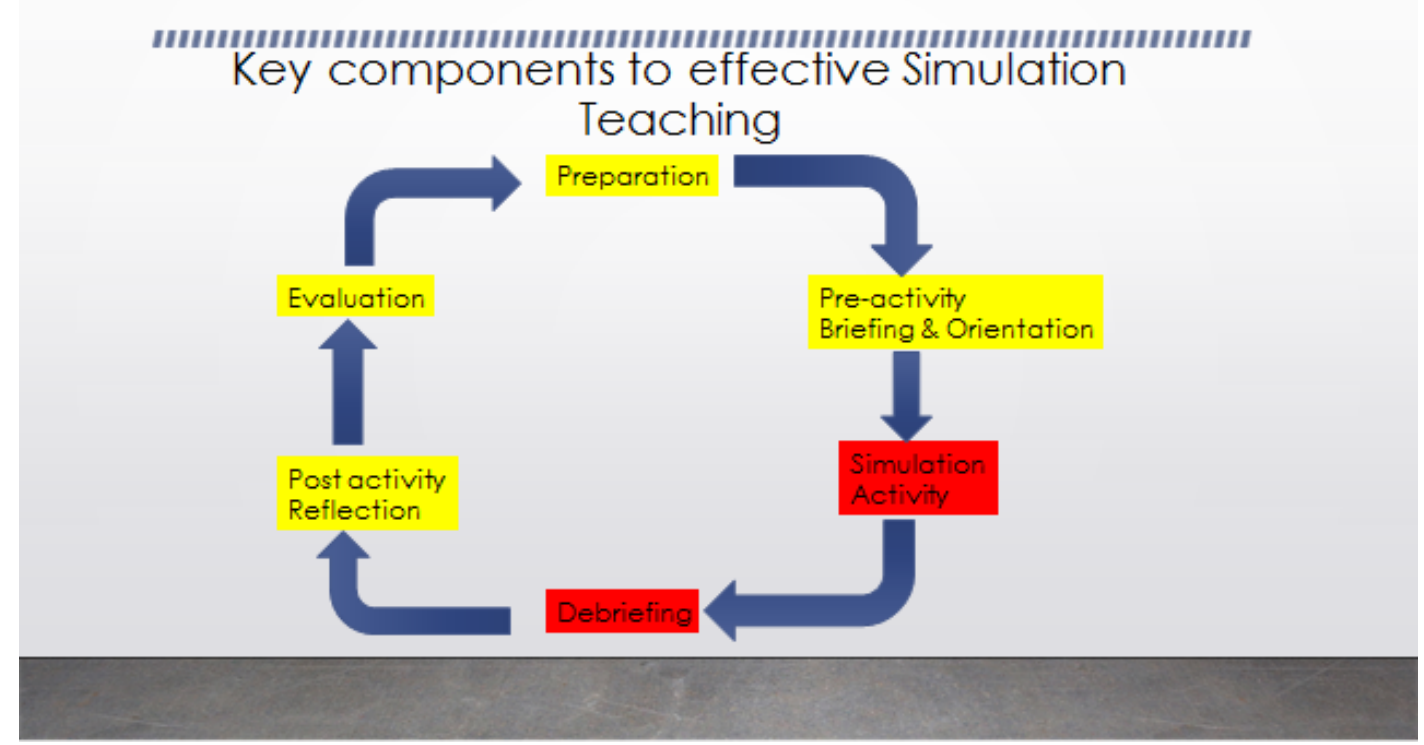

FIGURE 3. The Cycle of Simulation Teaching (adapted from Nestel \& Gough 2018)

\section{COMPREHENSIVE SIMULATION IN HEALTHCARE EDUCATION 4.0}

Centers for comprehensive simulation in healthcare training and education have started to sprout around the globe. Such centers, like the MSR (Israel Centre for Medical Simulation) (Aggarwal et al. 2010), provide a fully simulated medical environment that includes prehospital as well as inpatient settings with an extensive audiovisual network for debriefing and feedback. Healthcare professionals in-training, e.g. house officers, may be sent here for a short simulated training prior to entering the real working world. This may be the best and safest way forward in terms of training healthcare professionals at all levels, whilst adhering to most if not all principles of Education 4.0.

\section{FUTURE RECOMMENDATIONS}

In future, every institution that deals with healthcare education has to have simulation as an essential part of its setup. It is therefore imperative to develop an adequate workforce of professional simulationists, supported by simulation technologists, to train subject matter experts to be adept at designing simulation programs and modules for teaching and learning. This capacity building must begin now, and the current tempo must be stepped up if we are serious on developing progressive and futureproof healthcare education.

\section{CONCLUSION}

Simulation provides the essence in terms of training approach for healthcare education that complies beautifully with Education 4.0. Whilst the importance of direct patient contact is undeniable, simulationists are set to steer the direction of healthcare education to a whole new world of make-belief, as never before, making simulation the heart and soul of future healthcare education. Simulation is definitely a tool for healthcare education to entrench a cultural shift towards empowering the learner to be competent, leading to better patient safety. Simulation should not be seen to replace the age-old bedside teaching method where the opportunities of learning only happens by chance. More appropriately, simulation forms a beautiful bridge that closes the educational gap left by traditional methods of teaching.

\section{REFERENCES}

Aggarwal, R., Mytton, O.T., Derbrew, M., Hananel, D., Heydenburg, M., Issenberg, B., MacAulay, C., Mancini, M.E., Morimoto, T., Soper, N., Ziv, A. \& Reznick, R. 2010. Training and simulation for patient safety. Qual. Saf. Health Care 19(Suppl 2): 34-43.

Cooper, J.B. \& Taqueti, V.R. 2004. A brief history of the development of mannequin simulators for clinical education and training. Qual. Saf. Health Care 13(Suppl 1): 11-18.

Fida, M. \& Kassab, S.E. 2015. Do medical students' scores using different assessment instruments predict their scores in 
clinical reasoning using a computer-based simulation? $A d v$. Med. Educ. Pract. 6: 135-141.

Fisk, P. 2017. Education 4.0... The Future of Learning Will Be Dramatically Different, in School and Throughout Life. http://www.thegeniusworks.com/2017/01/future-educationyoungeveryone-taught-together. Accessed on 19 September 2019.

Gaba, D.M. 2004. The future vision of simulation in health care. Qual. Saf. Health Care 13(Suppl 1): 2-10.

Horgan, M. 2013. Communication is key. WIN 21(1): 46-47.

Humphrey-Murto, S., Wood, T.J., Ross, S., Tavares, W., Kvern, B., Sidhu, R., Sargeant, J. \& Touchie, C. 2017. Assessment pearls for competency-based medical education. J. Grad. Med. Educ. 9(6): 688-691.

Hussin, A.A. 2018. Education 4.0 made simple: Ideas for teaching. Int. J. Educ. Lit. Stud. 6(3): 92-98.

Intelitek 2018. The Education 4.0 Revolution: An Analysis of Industry 4.0 and Its Effect on Education. http://www.intelitek. com/what-is-education-4-0. Accessed on 19 September 2019.

Ismail, M.S., Johar, M.J., Siraj, H.H., Arif, K., Jalina, K., Iva, M.I., Saidah, M.H., Balakrishnan, M., Syahira, J. \& Phrampus, P.E. 2019. Influence of simulation in Malaysian healthcare education and research (ISIM-HERE): A twodecade experience. Med. Health 14(1): 53-67.

Ismail, M.S., Jaafar, M.J., Ahmad, N.S., Nasarudin, N.M.A., Mohamad, N., Ahmad, M.R. \& Gilbert, J.H.V. 2014. Emergency skills learning on video (ESLOV): A singleblinded randomized control trial of teaching common emergency skills using self-instruction video (SIV) versus traditional face-to-face (FTF) methods. Med. Teach. 36(3): 245-250.

Issenberg, S.B., McGaghie, W.C., Petrusa, E.R., Gordon, D.L. \& Scalese, R.J. 2005. Features and uses of high-fidelity medical simulations that lead to effective learning: A BEME systematic review. Med. Teach. 27(1): 10-28.

Montgomery, C., Kardong-Edgren, S.E., Oermann, M.H. \& Odom-Maryon, T. 2012. Student satisfaction and self-report of CPR competency: HeartCode ${ }^{\mathrm{TM}}$ BLS courses, instructorled CPR courses, and monthly voice advisory manikin practice for CPR skill maintenance. Int. J. Nurs. Edu. Scholarsh. 9(1): 1-14

Nestel, D. \& Gough, S. 2018. Designing simulation-based learning activities: A systematic approach. In Healthcare Simulation Education: Evidence, Theory and Practice, edited by Nestel, D., Kelly, M., Jolly, B. \& Watson, M. West Sussex: John Wiley \& Sons Ltd.
O'Brien, G. 2015. The Malaysian Qualifications Framework. www.slideplayer.com. (Google search: mqf para 15). Accessed on 24 February 2019.

Riley, B. 2015. Using simulation-based medical education to meet the competency requirements for the single accreditation system. J. Am. Osteopath. Assoc. 115(8): 504-508.

Satava, R.M. 2009. The revolution in medical education - the role of simulation. J. Grad. Med. Educ. 1(2): 172-175.

Taras, J. \& Everett, T. 2017. Rapid cycle deliberate practice in medical education - A systematic review. Cureus 9(4): e1180.

Wong, J., Goh, Q.Y., Tan, Z., Lie, S.A., Tay, Y.C. \& Ng, S.Y. 2020. Preparing for a COVID-19 pandemic: A review of operating room outbreak response measures in a large tertiary hospital in Singapore. Can. J. Anaesth. 67(6): 732-745.

Zaleha Abdullah Mahdy \& Ixora Kamisan Atan

Department of Obstetrics and Gynaecology

Faculty of Medicine

Universiti Kebangsaan Malaysia Medical Centre

Jalan Yaacob Latif, Bandar Tun Razak

56000 Cheras, Kuala Lumpur, Federal Territory

Malaysia

Muhammad Maaya

Department of Anaesthesiology \& Intensive Care

Faculty of Medicine

Universiti Kebangsaan Malaysia Medical Centre

Jalan Yaacob Latif, Bandar Tun Razak

56000 Cheras, Kuala Lumpur, Federal Territory

Malaysia

Azlan Helmy Abd Samat, Mohd Hisham Isa \& Ismail Mohd Saiboon*

Department of Emergency Medicine

Faculty of Medicine

Universiti Kebangsaan Malaysia Medical Centre

Jalan Yaacob Latif, Bandar Tun Razak

56000 Cheras, Kuala Lumpur, Federal Territory

Malaysia

*Corresponding author; email: fadzmail69@yahoo.com.my

Received: 1 October 2019

Accepted: 1 April 2020 